\title{
Peningkatan Kinerja Guru Melalui Supervisi Kepala Sekolah pada Sekolah Dasar
}

\section{Nyoman Sanglah1*}

${ }^{1}$ SD Negeri 2 Tegal Jadi, Tabanan, Indonesia

\section{ART ICLE INFO}

\section{Article history:}

Received August 08, 2021

Revised August 10, 2021

Accepted September 14, 2021

Available online October 25, 2021

Kata Kunci:

Motivasi Kerja, Kinerja Guru, Dan

Supervisi Kepala Sekolah

Keywords:

Work Motivation, Teacher

Performance, And Principal

Supervision

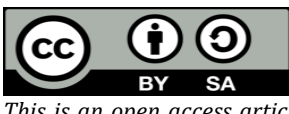

This is an open access article under the CC BY-SA license.

Copyright (C) 2021 by Author. Published by Universitas Pendidikan Ganesha.

\begin{abstract}
A B S T R A K
Dalam rangka melaksanakan tugas dan tanggung jawabnya seorang guru dituntut memiliki beberapa kemampuan dan ketrampilan, yang ditunjukkan dalam bentuk kinerja seorang guru. Hanya saja tidak semua guru memiliki kualitas kinerja yang baik, sehingga perlu dilalukan berbagai macam upaya untuk meningkatkan kinerja guru tersebut. Adapun tujuan dari penelitian ini yakni untuk mengetahui upaya peningkatan kinerja guru melalui supervisi kepala sekolah. Penelitian ini merupakan jenis penelitian tindakan, yang dilaksanakan dalam 2 siklus penelitian yakni siklus I dan siklus II. Pada masing-masing siklus terdapat tahap perencanaan, tindakan, observasi serta evaluasi dan refleksi. Subjek yang terlibat dalam penelitian ini berjumlah 10 orang, yang terdiri dari 9 orang guru dan 1 orang pegawai tata usaha. Pengumpulan data dalam penelitian dilakukan dengan menggunakan teknik observasi, wawancara, dokumentasi dan pemberian kuisioner. Data hasil penelitian kemudian dianalisis dengan menggunakan teknik analisis analisis statistik deskriptif yaitu dengan mencari rata-rata peningkatakan kinerja guru yang kemudian dikonfersikan kedalam PAP skala lima untuk menentukan tinggi kinerja guru setelah dilakukan supervisi kepala sekolah. Hasil penelitian menunjukkan bahwa terdapat peningkatan kinerja guru pada setiap siklusnya dimana pada tahap prasiklus rata-rata penilaian kinerja hanya mencapai 75\%, kemudian meningkat pada siklus I menjadi 90\%, dan meningkat kembali pada siklus II menjadi $100 \%$, dimana semua guru telah memiliki kinerja yang baik. Sehingga berdasarkan hasil tersebut dapat disimpulkan bahwa secara signifikan supervisi kepala sekolah dapat meningkatkan kinerja guru.
\end{abstract}

\section{A B S T RACT}

To carry out its duties and responsibilities, a teacher is required to have several abilities and skills, which are shown in the form of a teacher's performance. It's just that not all teachers have good performance qualities, so it is necessary to make various kinds of efforts to improve the performance of these teachers. The purpose of this research is to find out efforts to improve teacher performance through the supervision of the principal. This research is a type of action research, which is carried out in 2 research cycles, namely, cycle I and cycle II. In each cycle, there are stages of planning, action, observation and evaluation, and reflection. The subjects involved in this study were 10 people, consisting of 9 teachers and 1 administrative employee. Data collection in the study was carried out using observation, interviews, documentation, and questionnaires. The research data were then analyzed using descriptive statistical analysis techniques, namely by looking for the average teacher performance improvement which was then converted into a fivescale PAP to determine the teacher's high performance after supervision by the principal. The results showed that there was an increase in teacher performance in each cycle where at the pre-cycle stage the average performance appraisal only reached $75 \%$, then increased in the first cycle to $90 \%$, and increased again in the second cycle to $100 \%$, where all teachers have had a good performance. the good one. So based on these results it can be concluded that the principal's supervision can significantly improve teacher performance.

\section{PENDAHULUAN}

Pendidikan merupakan upaya yang dilakukan untuk mengembangkan berbagai potensi serta kemampuan seorang individu, sehingga nantinya individu tersebut dapat memiliki kekuatan spiritual keagamaan, pengendalian diri, kepribadian, kecerdasan, akhlak mulia, serta ketrampilan yang diperlukan dirinya, masyarakat, Bangsa dan Negara (Abidin, 2019; Astawa, 2017; Sujana, 2019). Melalui pendidikan seseorang akan dapat diterima dengan baik oleh masyarakat, sehingga akan memberikan dampak pada peningkatan kualitas hidup (Friantary, 2019). Di Indonesia pelaksanaan pendidikan lebih ditekankan pada pengembangan sikap, keterampilan, dan pengatahuan. Dalam pelaksanaan pendidikan, terdapat berbagai komponen pendidikan seperti guru, peserta didik, serta sarana dan prasarana penunjang 
pendidikan (Ahmadi et al., 2020). Setiap komponen pendidikan harus bekerja sama untuk menciptakan pendidikan yang berkualitas dan mampu meningkatkan sumber daya manusia.

Salah satu komponen penting dalam pendidikan yakni guru atau tenaga pendidik. Guru atau tenaga pendidik merupakan tenaga profesional yang bertugas merencanakan dan melaksanakan proses pembelajaran, menilai hasil pembelajaran, melakukan pembimbingan dan pelatihan, serta melakukan penelitian dan pengabdian kepada masyarakat, terutama bagi pendidik pada perguruan tinggi (Anwar, 2020; Mulyani, 2019; Syaifullah, 2018). Untuk dapat melaksanakan tugas dan tanggung jawab di atas, seorang guru dituntut memiliki beberapa kemampuan dan ketrampilan tertentu. Kemampuan dan ketrampilan tersebut sebagai bagian dari kompetensi profesionalisme guru (Notanubun, 2019; Rahmawati \& Astuti, 2017). Kinerja guru atau prestasi kerja adalah suatu hasil kerja yang dicapai seseorang dalam melaksanakan tugas-tugas yang dibebankan kepadanya yang didasarkan atas kecakapan, pengalaman, dan kesungguhan serta waktu (Arini, 2019; Rivai, 2021).

Selain kinerja, motivasi guru dalam melakukan tugas dan tanggung jawab juga merupakan hal penting, sebagai upaya meningkatkan proses pembelajaran yang akan dapat meningkatkan kualitas pendidikan yang ada (Diwiyani \& Sarino, 2018; Harefa, 2020). Motivasi kerja pada dasarnya merupakan sesuatu yang menimbulkan semangat atau dorongan dan kerja (Amalda \& Prasojo, 2018; Ratnawati \& Atmaja, 2020). Oleh sebab itu, motivasi kerja dalam psikologi sebagai pendorong semangat kerja. Guru menjadi seorang pendidik karena adanya motivasi untuk mendidik. Bila tidak punya motivasi maka ia tidak akan berhasil untuk mendidik/mengajar. Keberhasilan guru dalam mengajar karena dorongan/motivasi ini sebagai pertanda apa yang telah dilakukan oleh guru telah menyentuh kebutuhannya. Kegiatan mengajar yang dilakukan oleh guru yang diminatinya karena sesuai dengan kepentingannya sendiri. Guru yang termotivasi dalam bekerja maka akan menimbulkan kepuasan kerja, karena kebutuhan-kebutuhan guru yang terpenuhi mendorong guru meningkatkan kinerjanya.

Hanya saja permasalahan yang sering terjadi dilapangan menunjukkan bahwa masih terdapat beberapa guru yang memiliki kinerja serta motivasi kurang (Anwar, 2020; Dewi, 2018; Selfiati et al., 2021). Hal ini sejalan dengan hasil observasi yang dilakukan di SD Negeri 2 Tegaljadi. Hasil observasi menunjukkan bahwa masih terdapat beberapa guru yang memiliki kinerja serta motivasi mengajar rendah. Hal ini ditunjukkan dengan adanya beberapa guru yang absen pada hari efektif tanpa adanya surat keterangan, selain itu terdapat pula beberapa guru yang melas untuk melaksanakan proses pembelajaran sehingga siswa hanya diberikan tugas, tanpa memberikan pemahaman materi. Rendahnya kinerja guru tersebut jika dibiarkan secara terus menerus akan berdampak pada rendahnya kualitas pembelajaran yang ada di sekolah. Untuk itu perlu upaya yang dapat dilakukan dalam rangka mempertahankan sekaligus meningkatkan kinerja guru di sekolah. Salah satu upaya yang dirasakan paling efektif dalam rangka meningkatkan kinerja dan motivasi kerja guru adalah mengoptimalkan peran kepala sekolah melalui supervisi.

Supervisi pendidikan diartikan sebagai suatu proses pemberian layanan bantuan profesional kepada guru untuk meningkatkan kemampuannya dalam melaksanakan tugas-tugas pengelolaan proses pembelajaran secara efektif dan efisien (Asyari, 2020; Raberi et al., 2020). Pelaksanaan supervisi dapat dilakukan dengan memberikan perhatian terhadap kegiatan-kegiatan supervisi kepala kelas, memberikan perhatian terhadap kesejahteraan guru, memotivasi guru (Sohim et al., 2021; Werdiningsih, 2021). Supervisi menjadi salah satu upaya yang dilakukan oleh kepala sekolah untuk memperbaiki situasi belajar mengajar, sehingga mampu meningkatkan kualitas pembelajaran di sekolah (Suchyadi et al., 2019). Beberapa penelitian yang telah dilakukan sebelumnya menyebutkan bahwa supervisi kepala sekolah memiliki pengaruh yang positif dan signifikan terhadap kinerja guru disekolah (Aprida et al., 2020). Hal senada juga disebutkan oleh penelitian selanjutnya yang menyebutkan bahwa supervisi akademik kepala sekolah berpengaruh positif dan signifikan terhadap kinerja guru Sekolah Dasar (Pujianto et al., 2020). Penelitian lainnya menyebutkan bahwa selain mampu meningkatkan kinerja guru supervisi kepala sekolah juga dapat meningkatkan motivasi kerja seorang guru (Nisa et al., 2021). Berdasarkan beberapa penelitian yang telah dilakukan sebelumnya dapat dikatakan bahwa supervisi kepala sekolah secara signifikan mampu meningkatkan kinerja guru, sehingga berdampak pada peningkatan kualitas pembelajaran. Hanya saja penelitian sebelumnya belum terdapat kajian mengenai upaya meningkatkan kinerja guru melalui supervisi kepala sekolah pada Sekolah Dasar Negeri 2 Tegaljadi tahun pelajaran 2018/2019, sehingga penelitian ini difokuskan pada hal tersebut dengan tujuan untuk mengetahui upaya peningkatan kinerja guru melalui supervisi kepala sekolah yang ada di SD Negeri 2 Tegaljadi. 


\section{METODE}

Penelitian ini adalah penelitian tindakan model yang dilakukan dengan menggunakan sistem empat komponen penelitian yang dimulai dari perencanaan tindakan, pengamatan, refleksi, dan perencanaan kembali yang merupakan dasar pemecahan masalah. Penelitian dilakukan dalam 2 siklus penelitian dimana pada masing-masing siklus terdapat tahap perencanaan, tindakan, observasi serta evaluasi dan refleksi. Adapun langkah-langkah penelitian tindakan dapat dilihat pada Gambar 1.

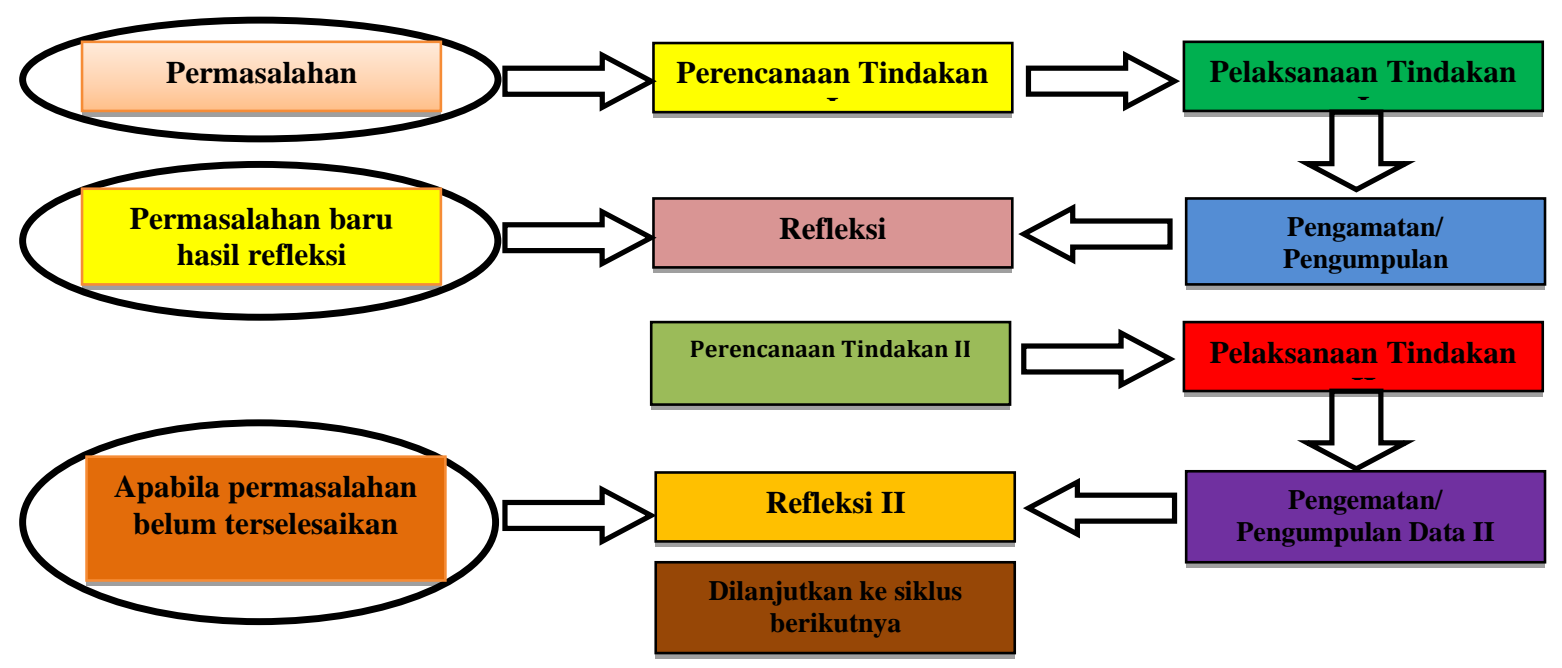

Gambar 1. Alur Penelitian Tindakan Kelas

Subjek yang terlibat dalam penelitian tindakan sekolah ini adalah guru-guru di SD Negeri 2 Tegaljadi yang berjumlah 10 orang, yang terdiri dari 9 orang guru dan 1 orang pegawai tata usaha. Waktu penelitian dilakukan pada bulan September sampai Oktober 2018. Data yang dikumpulkan untuk penelitian ini berupa data primer. Data primer ini merupakan data yang dihasilkan untuk memenuhi kebutuhan penyelidikan yang sedang ditangani. Pengumpulan data dalam penelitian dilakukan dengan teknik pemberian kuisioner, observasi, wawancara, serta dokumentasi. Data hasil penelitian kemudian dianalisis menggunakan teknik analisis statistik deskriptif yaitu dengan mencari rata-rata peningkatakan kinerja guru yang kemudian dikonfersikan kedalam PAP skala lima untuk menentukan tinggi kinerja guru setelah dilakukan supervisi kepala sekolah.

\section{HASIL DAN PEMBAHASAN}

Hasil

Kegiatan penelitian diawali pada tahap prasiklus dengan melakukan observasi untuk mengetahui keadaan awal kinerja guru. Hasil penilaian kondisi awal kinerja guru yang ada di SD Negeri 2 Tegaljadi Mengwi Tahun Pelajaran 2018/2019 menunjukkan bahwa penilaian kinerja guru pada kondisi awal (pra siklus) menunjukkan bahwa guru yang mempunyai penilaian kinerja yang cukup baik ada 9 orang atau mencapai $75 \%$ dari total guru yang diamati. Sedangkan guru yang mempunyai penilaian kinerja yang kurang baik terdapat 1 guru atau $25 \%$ dari total guru yang diamati dalam penelitian ini. Selain itu dapat dketahui bahwa rata-rata penilaian kinerja guru pada kondisi awal (pra siklus) menunjukkan nilai 5,98 atau masuk dalam kategori kurang baik. Dengan demikian dapat diketahui bahwa kinerja guru yang ada di SD Negeri 2 Tegaljadi Mengwi sebelum adanya tindakan supervisi kepala sekolah masih sangat rendah. Berdasarkan hasil penilaian terhadap kondisi awal terkait dengan penilaian kinerja guru yang masih rendah, maka perlu mendapatkan tindakan untuk dapat meningkatkan kinerja guru. Salah satu upaya yang diterapkan di SD Negeri 2 Tegaljadi, yaitu dengan melaksanakan observasi dan supervisi kelas. Untuk meningkatkan kinerja guru penelitian dilanjutkan pada siklus I. Dalam siklus I dilaksanakan sebagai bentuk upaya untuk dapat mengatasi masalah rendahnya motivasi dan kinerja guru yang ada di SD Negeri 2 Tegaljadi Mengwi. Dalam pelaksanaan observasi dan supervisi guru pada siklus I dilakukan dengan menggunakan teknik supervisi perorangan seperti kunjungan kelas, percakapan pribadi, kunjungan antar kelas, penilaian sendiri. Sedang teknik supervisi kelompok meliputi kegiatan kepanitiaan, kursus, laboratorium kelompok, bacaan terpimpin, demonstrasi pembelajaran, perjalanan staf, diskusi panel, perpustakaan profesional, organisasi profesional, bulletin supervisi, sertifikasi guru, tugas belajar, pertemuan guru. Dari hasil pelaksanaan supervisi tersebut guru akan dapat melakukan penilaian atau 
evaluasi kinerja guru yang sesungguhnya. Supervisi dilakukan tanpa adanya pemberitahuan terlebih dahulu. Dalam setiap pelaksanaan supervisi kepala sekolah memberikan penilaian terhadap aspek kinerja sesuai dengan yang telah direncanakan untuk mengetahui penilaian motivasi dan kinerja setiap guru dalam proses pembelajaran.

Berdasarkan penilaian kinerja guru pada siklus I dapat diketahui bahwa guru yang mempunyai penilaian kinerja yang cukup baik ada 9 orang atau mencapai $90 \%$ dari total guru yang diamati. Sedangkan guru yang mempunyai penilaian kinerja yang baik terdapat 1 guru atau 10\% dari total guru yang diamati dalam penelitian ini. Selain itu dapat dketahui bahwa rata-rata penilaian kinerja guru pada siklus I menunjukkan nilai 6,69 atau masuk dalam kategori cukup baik. Dengan demikian dapat diketahui bahwa kinerja guru yang ada di SD Negeri 2 Tegaljadi tahun 2018/2019 mengalami peningkatan setelah dilaksanakannya supervisi guru. Dari yang semula mempunyai rata-rata penilaian 5,95 meningkat menjadi 6,69. Meskipun demikian peningkatan motivasi dan kinerja guru pada siklus ini belum mampu mencapai target yang telah ditetapkan yaitu 75\% guru mempunyai penilaian motivasi dan kinerja yang baik. Dari hasil pelaksanaan supervisi guru pada siklus I masih terdapat banyak kekurangan yang masih perlu diperbaiki agar mampu menghasilkan aktivitas supervisi yang efektif. Dimana dalam pelaksanaan supervisi pada siklus I belum dilaksanakan secara matang mengingat perencanaan yang dilakukan masih terbatas pada perencanaan yang sederhana. Perencanaan kegiatan supervisi yang dilaksanakan pada siklus I belum dilakukan secara trstruktur dengan baik. Selain itu kurangnya koordinasi antara kepala sekolah dengan guru dalam pelaksanaan supervisi. Kepala sekolah kurang dapat memanfaatkan fasilitas dan sumber daya yang ada di sekolah guna mendukung kegiatan supervisi. Sebagai bentuk refleksi dalampenelitian ini, masih dibutuhkan perencanaan yang lebih matang untuk menghasilkan supervisi kepala sekolah yang lebih efektif. Selain itu diperlukan adanya koordinasi antara kepala sekolah dengan guru guna meningkatkan efektifitas pelaksanaan supervisi ini. Untuk itu dalam pelaksanaan supervisi ini perlu dilakukan perbaikan pada siklus II.

Siklus II dilaksanakan sebagai bentuk refleksi dari pelaksanaan supervisi kepala sekolah yang telah dilakukan pada siklus I dalam rangka meningkatkan kinerja guru di SD Negeri 2 Tegaljadi Mengwi tahun pelajaran 2018/2019. Pelaksanaan supervisi kepala sekolah pada siklus II pada dasarnya sama dengan apa yang telah dilaksanakan pada siklus I dengan menggunakan teknik supervisi perorangan seperti: kunjungan kelas, percakapan pribadi, kunjungan antar kelas, penilaian sendiri. Sedang teknik supervisi kelompok meliputi: kepanitiaan, kursus, laboratorium kelompok, bacaan terpimpin, demonstrasi pembelajaran, perjalanan staf, diskusi panel, perpustakaan profesional, organisasi profesional, bulletin supervisi, sertifikasi guru, tugas belajar, pertemuan guru. Meskipun demikian pelaksanaan supervisi pada siklus II ini dilakukan perencanaan yang lebih matang dengan melibatkan guru dan melakukan koordinasi antara kepala sekolah dengan guru dalam rangka upaya meningkatkan motivasi dan kinerja guru. Kepala sekolah lebih serius dalam melakukan kegiatan supervisi. Kepala sekolah secara rutin melakukan kunjungan ke masing-masing kelas, melakukan diskusi dengan guru kelas, menanyakan tentang keadaan dan perkembangan kelas yang diasuh masing-masing guru, kepala sekolah juga melibatkan guru-guru dalam aktivitas diluar kelas, dan kepala sekolah juga memberikan kesempatan kepada guru untuk berupaya mengembangkan kreativitasnya dalam mengajar. Kepala sekolah juga memberikan arahan kepada setiap guru untuk memanfaatkan segala fasilitas dan sumber daya yang ada di sekolah guna mendukung proses belajar yang lebih baik.

Dalam pelaksanaan supervisi pada siklus II ini, kepala sekolah juga menanyakan kepada anak didik dan wali murid tentang kondisi belajar yang ada di kelas masing-masing, selain itu kepala sekolah juga selalu berupaya untuk memberikan dukungan baik fisik maupun mental terhadap semua guru maupun peserta didik dalam meningkatkan prestasi belajar peserta didik. Kepala sekolah selalu memberikan kesempatan kepada para guru untuk menyempaikan aspirasi atau pendapatnya dalam upaya mengembangkan proses belajar di sekolah. Dengan adanya kegiatan supervisi pada siklus II ini, maka dapat diketahui hasil penilaian terhadap kinerja guru di SD Negeri 2 Tegaljadi. Berdasarkan penilaian kinerja guru pada siklus II dapat diketahui bahwa terdapat 10 guru atau $100 \%$ dari seluruh guru yang diamati dalam penelitian yang sudah mampu menunjukkan kinerja yang baik. Dengan demikian dapat diketahui bahwa target pencapaian dalam pelaksanaan tindakan pada penelitian ini sudah tercapai. Dimana lebih dari 75\% guru telah mampu mendapatkan penilaian motivasi yang baik.

\section{Pembahasan}

Berdasarkan hasil penelitian tindakan sekolah yang terkait dengan upaya meningkatkan kinerja guru melalui pelaksanaan supervisi kepala sekolah menunjukkan bahwa terdapat peningkatan kinerja guru setelah dilaksanakan supervisi kepala sekolah. Kinerja guru pada dasarnya merupakan hasil kerja yang dicapai oleh seorang guru dalam melaksanakan tugas mendidik, mengajar, membimbing, mengarahkan, melatih, menilai, dan mengevaluasi peserta didik (Putri \& Imaniyati, 2017; Saifullah, 2020). 
Kinerja seorang guru dapat dilihat dari prestasi yang diperoleh oleh seorang guru, bagaimana seorang guru melaksanakan proses pembelajaran dan mengevaluasi hasil pembelajaran serta memberikan tindak lanjut dari evaluasi pembelajaran, dan hasil kerja yang diperoleh oleh seorang guru (Noor, 2018; Tengko et al., 2021). Peningkatan kualitas pendidikan sangat bergantung pada kinerja guru. Kinerja guru yang baik akan berpengaruh terhadap proses belajar siswa, seorang guru yang memiliki kinerja yang baik tentunya akan mampu melaksanakan proses pembelajaran dengan baik serta mampu mengkondisikan kelasnya dengan baik (Pane \& Darwis Dasopang, 2017; Putri \& Imaniyati, 2017). Kualitas kinerja dapat dipengaruhi oleh faktor internal maupun eksternal. Faktor internal dapat berupa motivasi kerja serta kondisi fisik dan psikis seorang guru (Kamijan, 2021). Guru yang memiliki motivasi kerja serta memiliki dorongan dalam diri untuk melaksanakan pendidikan yang bermakna akan berdampak pada peningkatan kinerja guru tersebut begitu pula sebaliknya (Rivai, 2021; Sya'roni et al., 2018). Selain itu kondisi fisik serta psikis guru juga akan mempengaruhi kinerja guru, guru yang memiliki kondisi fisik kurang sehat akan cenderung memiliki kinerja yang kurang baik, begitu pula sebaliknya (Pujianto et al., 2020).

Selain dipengaruhi oleh faktor internal, kinerja guru juga dipengaruhi oleh faktor eksternal seperti lingkungan kerja, budaya sekolah, gaya kepemimpinan serta supervisi kepala sekolah (Pratiwi \& Negara, 2021; Utami \& Negara, 2021). Jika ada salah satu komponen peningkatan kinerja tidak dalam kondisi optimal maka kualitas kinerja juga kurang optimal. Salah satu faktor yang dapat mempengaruhi kinerja guru secara signifikan adalah supervisi kepala sekolah. Supervisi kepala sekolah pada dasarnya merupakan kegiatan akademik yang dilakukan oleh kepala sekolah untuk membantu guru mengembangkan kemampuan mengelola proses pembelajaran demi tercapinya tujuan pembelajaran (Ginting, 2020). Tujuan pelaksanaan program supervisi adalah membantu guru dalam meningkatkan kinerja sekaligus mutu pendidikan. Kegiatan supervisi umumnya difokuskan pada pengembangan profesionalitas guru melalui kegiatan pelatihan dan pembinaan, workshop, serta pemberian dorongan dan penghargaan kepada guru berprestasi (Sohim et al., 2021). Hasil yang diperoleh pada penelitian ini sejalan dengan hasil penelitian terdahulu yang juga menyebutkan bahwa supervisi kepala sekolah memiliki pengaruh yang positif dan signifikan terhadap kinerja guru disekolah (Aprida et al., 2020). Hal senada juga disebutkan oleh penelitian selanjutnya yang menyebutkan bahwa supervisi akademik kepala sekolah berpengaruh positif dan signifikan terhadap kinerja guru Sekolah Dasar (Pujianto et al., 2020). Penelitian lainnya menyebutkan bahwa selain mampu meningkatkan kinerja guru supervisi kepala sekolah juga dapat meningkatkan motivasi kerja seorang guru (Nisa et al., 2021). Sehingga berdasarkan hal tersebut dapat dikatakan bahwa kegiatan supervisi dapat memberikan pengaruh yang positif terhadap peningkatan kinerja guru.

\section{SIMPULAN}

Pelaksanaan supervisi kepala sekolah terbukti dapat meningkatkan kinerja guru di SD Negeri 2 Tegaljadi Tahun Pelajaran 2018/2019 terlihat dari peningkatan nilai supervise pada kinerja guru dari tahap prasiklu, siklus I, dan siklus II..

\section{DAFTAR PUSTAKA}

Abidin, M. (2019). Penerapan Pendidikan Karakter Pada Kegiatan Ekstrakurikuler Melalui Metode Pembiasaan. Didaktika: Jurnal Kependidikan, 183-196. https://doi.org/10.30863/didaktika.v12i2.185.

Ahmadi, M. Z., Haris, H., \& Akbal, M. (2020). Implementasi Program Penguatan Pendidikan Karakter Di Sekolah. Phinisi Integration Review, 3(2), 305. https://doi.org/10.26858/pir.v3i2.14971.

Amalda, N., \& Prasojo, L. D. (2018). Pengaruh motivasi kerja guru, disiplin kerja guru, dan kedisiplinan siswa terhadap prestasi belajar siswa. Jurnal Akuntabilitas Manajemen Pendidikan, 6(1), 11. https://doi.org/10.21831/amp.v6i1.7515.

Anwar, A. S. (2020). Pengembangan Sikap Profesionalisme Guru Melalui Kinerja Guru Pada Satuan Pendidikan MTS Negeri 1 Serang. Andragogi: Jurnal Pendidikan Islam Dan Manajemen Pendidikan Islam, 2(1), 147-173. https://doi.org/10.36671/andragogi.v2i1.79.

Aprida, Y., Fitria, H., \& Nurkhalis, N. (2020). Pengaruh Supervisi Kepala Sekolah dan Motivasi Kerja Guru Terhadap Kinerja Guru. Journal of Education Research, 1(2), 160-164. https://doi.org/10.37985/joe.v1i2.16.

Arini, N. W. (2019). Peningkatan Kinerja Guru Sekolah Dasar Dalam Mencapai Hasil Belajar Siswa. Adi Widya: Jurnal Pendidikan Dasar, 4(2), 126. https://doi.org/10.25078/aw.v4i2.1114.

Astawa, I. N. T. (2017). Memahami Peran Masyarakat Dan Pemerintah Dalam Kemajuan Mutu Pendidikan Di Indonesia. Jurnal Penjaminan Mutu, 3(2), 197. https://doi.org/10.25078/jpm.v3i2.200. 
Asyari, S. (2020). Supervisi Kepala Madrasah Berbasis Penilaian Kinerja sebagai Upaya Peningkatan Profesionalitas Guru. Jieman: Journal of Islamic Educational Management, 2(1). https://doi.org/10.35719/jieman.v2i1.14.

Dewi, R. S. (2018). Kemampuan Profesional Guru Dan Motivasi Kerja Terhadap Kinerja Mengajar Guru Sekolah Dasar. Jurnal Administrasi Pendidikan, 25(1), 150-159. https://doi.org/10.17509/jap.v25i1.11581.

Diwiyani, D., \& Sarino, A. (2018). Gaya Kepemimpinan Situasional Kepala Sekolah Dan Motivasi Kerja Guru Sebagai Determinan Kinerja Guru. Jurnal Manajerial, 17(1), 83. https://doi.org/10.17509/manajerial.v17i1.9763.

Friantary, H. (2019). Budaya Membaca Sebagai Upaya Peningkatan Kualitas Hidup Masyarakat. Disastra: Jurnal Pendidikan Bahasa Dan Sastra Indonesia, $1(1), \quad 66$. https://doi.org/10.29300/disastra.v1i1.1485.

Ginting, R. (2020). Fungsi Supervisi Kepala Sekolah terhadap Kinerja Guru. Jurnal Edukasi Nonformal, 1(2), 88-92. https://ummaspul.e-journal.id/JENFOL/article/view/409/230.

Harefa, D. (2020). Pengaruh Antara Motivasi Kerja Guru IPA dan Displin Dengan Prestasi Kerja. Aksara: Jurnal Ilmu Pendidikan Nonformal, 6(3), 225. https://doi.org/10.37905/aksara.6.3.225-240.2020.

Kamijan, Y. (2021). Faktor Internal Dan Faktor Eksternalterhadap Kinerja Guru Di Masa Pandemi Covid19. Jurnal Ekonomi Manajemen Sistem Informasi, 2(5), 630-638. https://doi.org/10.31933/jemsi.v2i5.589.

Mulyani, N. (2019). Pengembangan Profesionalisme Guru Pada MTSN 1 Serang Melalui Peningkatan Kompetensi Profesional Dan Pedagogik. Tarbawi: Jurnal Keilmuan Manajemen Pendidikan, 5(01), 87. https://doi.org/10.32678/tarbawi.v5i01.1826.

Nisa, N. Z., Sunandar, S., \& Miyono, N. (2021). Pengaruh Supervisi Akademik Dan Iklim Organisasi Sekolah Terhadap Motivasi Kerja Guru Sekolah Menengah Pertama Di Kecamatan Kedung Kabupaten Jepara. Jurnal Manajemen Pendidikan (JMP), 9(2). https://doi.org/10.26877/jmp.v9i2.8114.

Noor, M. (2018). Peningkatan Kinerja Guru melalui Supervisi Edukatif Kolaboratif secara Periodik. Journal of Al-Adzka: Jurnal Ilmiah Pendidikan Guru Madrasah Ibtidaiyah, 8(1), 45. https://doi.org/10.18592/aladzkapgmi.v8i1.2177.

Notanubun, Z. (2019). Pengembangan Kompetensi Profesionalisme Guru di Era Digital (Abad 21). Jurnal Bimbingan Dan Konseling Terapan, 3(2). https://doi.org/ 10.30598/jbkt.v3i2.1108.

Pane, A., \& Darwis Dasopang, M. (2017). Belajar Dan Pembelajaran. FITRAH:Jurnal Kajian Ilmu-Ilmu Keislaman, 3(2), 333. https://doi.org/10.24952/fitrah.v3i2.945.

Pratiwi, N. L. A. M., \& Negara, I. G. A. O. (2021). Kontribusi Kepemimpinan Kepala Sekolah dan Budaya Sekolah terhadap Kinerja Guru di SD. Jurnal Penelitian Dan Pengembangan Pendidikan, 5(1). https://doi.org/10.23887/jppp.v5i1.32884.

Pujianto, P., Arafat, Y., \& Setiawan, A. A. (2020). Pengaruh Supervisi Akademik Kepala Sekolah dan Lingkungan Kerja Terhadap Kinerja Guru Sekolah Dasar Negeri Air Salek. Journal of Education Research, 1(2), 106-113. https://doi.org/10.37985/joe.v1i2.8.

Putri, A. D. K., \& Imaniyati, N. (2017). Pengembangan Profesi Guru Dalam Meningkatkan Kinerja Guru. Jurnal Pendidikan Manajemen Perkantoran, 2(2), 93. https://doi.org/10.17509/jpm.v2i2.8109.

Raberi, A., Fitria, H., \& Fitriani, Y. (2020). Pengaruh Supervisi Kepala Sekolah dan Peran Komite Sekolah Terhadap Kinerja Guru. Jurnal Al-Qiyam, 1(2), 11-20. http://ojs.staialfurqan.ac.id/alqiyam/article/view/123/80.

Rahmawati, A. S., \& Astuti, A. P. (2017). Pengaruh Kompetensi Profesional Guru Kimia Terhadap Keterampilan Pembelajaran Laboratorium Siswa Kelas XII SMA N 11 Semarang. Jurnal Pendidikan Sains, 5(1). https://doi.org/10.26714/jps.5.1.2017.47-55.

Ratnawati, S., \& Atmaja, H. E. (2020). Pentingnya Kompetensi, Motivasi Dan Kepuasan Kerja Mendorong Prestasi Kerja. Jurnal Bisnis Dan Manajemen, 6(1). https://doi.org/10.47686/bbm.v6i01.283.

Rivai, A. (2021). Pengaruh Pengawasan, Disiplin dan Motivasi Terhadap Kinerja Guru. Jurnal Ilmiah Magister Manajemen, 4(1). https://doi.org/ 10.30596\%2Fmaneggio.v4i1.6715.

Saifullah, S. (2020). Determinasi Motivasi Dan Kinerja Guru Terhadap Kepemimpinan Kepala Sekolah Dan Kompetensi Profesional Guru (Studi Kasus Di SMAN Negeri 1 Kota Bima) Literature Review Manajemen Sumber Daya Manusia. Jurnal Manajemen Pendidikan Dan Ilmu Sosial, 1(2). https://doi.org/10.38035/jmpis.v1i2.340.

Selfiati, F., Lian, B., \& Wardarita, R. (2021). Pengaruh Kepemimpinan Kepala Sekolah dan Budaya Organisasi Terhadap Kinerja Guru SMP Se-Kecamatan Sako Palembang. Jurnal Pendidikan, 9(1). https://doi.org/10.36232/pendidikan.v9i1.604.

Sohim, B., Syah, S., \& Hanafiah, H. (2021). Kompetensi Manajemen Kepala Sekolah Dalam Meningkatkan Profesionalisme Guru PAI Di SMP Nurul Ihsan Banjaran Kabupaten Subang Jawa Barat. Jurnal 
Manjemen Pendidikan, 1(2). https://doi.org/ 10.31602/jmpd.v1i2.5133.

Suchyadi, Y., Karmila, N., \& Safitri, N. (2019). Kepuasan Kerja Guru Ditinjau Dari Peran Supervisi Kepala Sekolah Dasar Negeri Di Kecamatan Bogor Utara. Jurnal Pendidikan \& Pengajaran Guru Sekolah Dasar, 2(2), 91-94. https://doi.org/10.33751/jppguseda.v2i2.1453.

Sujana, I. W. C. (2019). Fungsi Dan Tujuan Pendidikan Indonesia. Adi Widya: Jurnal Pendidikan Dasar, 4(1), 29. https://doi.org/10.25078/aw.v4i1.927.

Sya'roni, Herlambang, T., \& Cahyono, D. (2018). Dampak Motivasi, Disiplin Kerja Dan Kepemimpinan Kepala Sekolah Terhadap Kinerja Guru. Jurnal Sains Manajemen Dan Bisnis Indonesia, 8(2). https: //doi.org/10.32528/jsmbi.v8i2.1785.

Syaifullah, S. (2018). Analisis Pengembangan Profesional Pendidik dan Tenaga Kependidikan di SMAN 2 Wera Kabupaten Bima. Edu Sociata (Jurnal Pendidikan Sosiologi ), 1(2), 1-9. https://doi.org/10.33627/es.v1i2.19.

Tengko, F., Limbong, M., \& Kailola, L. G. (2021). Pengaruh Supervisi Akademik Pengawas Sekolah Terhadap Kinerja Guru SMP di Kecamatan Tondon Kabupaten Toraja Utara. Attractive : Innovative Education Journal, 3(1), 13. https://doi.org/10.51278/aj.v3i1.203.

Utami, G. S., \& Negara, I. G. A. O. (2021). Kontribusi Budaya Sekolah dan Motivasi Kerja terhadap Kinerja Guru. Jurnal Pedagogi Dan Pembelajaran, 4(1), 168. https://doi.org/10.23887/jp2.v4i1.32218.

Werdiningsih, W. (2021). Manajemen Sumber Daya Manusia dalam Meningkatkan Kompetensi Guru Melaksanakan Pembelajaran Daring. Jurnal Manajemen Pendidikan Islam, 2(1). https://doi.org/https://doi.org/10.21154/sajiem.v2i1.48. 